\title{
Community Response to Amorphophallus sp. Agroindustrial Empowerment Using Partial Least Square
}

\author{
Ahmad Syihab Fahmil Qowim Romadhon Mubarok $^{1 *}$, Imam Santoso ${ }^{2}$ \\ Department of Agroindustrial Technology, Faculty of Agricultural Technology, Brawijaya University, \\ Veteran Street, Malang, East Java, Indonesia 65145
}

Received: 2 August 2018; Revised: 11 October 2018; Accepted: 30 October 2018

\begin{abstract}
Amorphophallus sp is one of the most important crops developed in Indonesia, both as food crops as well as industrial raw materials. This plant is widely developed in through various community empowerment programs such as farmer empowerment conducted by PERUM PERHUTANI Unit II of East Java in cultivated area of 1.605,3 Ha. This study focused to analyze the public response to Amorphophallus sp cultivation in empowering communities. The method used was quantitative approach and inferential statistics using Partial Least Square (PLS). The community, in the study area, already have the knowledge of Amorphophallus sp cultivation. The communities have experienced to implement postharvest practices such as chip. The community response on the implementation Amorphophallus sp cultivation has been good, and feel the benefits of cultivating mainly from the economic aspect. Due to economic factors, some people still sell the bulbs Amorphophallus sp without process into a more value-added products. PLS analysis showed that the variable of community attitude and participation significantly affected the benefits of cultivation in the community. The higher the participation, the better the achievement of community empowerment. However, the variable of cultivation information, the variable of the information of post-harvest handling, and the variable of supporting facilities did not significantly influence the community response. Furthermore, the variable of cultivation information, the variable of information of post-harvest handling, the variable of supporting facilities, the variable of society attitude did not significantly influence on the community participation.
\end{abstract}

Keywords: Amorphophallus sp; empowerment; Partial Least Square (PLS)

How to cite:

Syihab, A., Qowim, F., Mubarok, R., \& Santoso, I. (2018). Community Response to Amorphophallus sp. Agroindustrial Empowerment Using Partial Least Square. HABITAT, 29(3), 99-105. https://doi.org/10.21776/ub.habitat.2018.029.3.12

\section{Introduction}

Local plants, especially root crops, have an important role in supporting food security and the agroindustrial development. It is because each region has its specific advantages in accordance with the support of the natural resources. One potential food crops, which deserves to be developed in Indonesia, is Amorphophallus $s p$ (Figure 1). It is one plant that is suitable and can flourish in the tropics. Additionally, it can also grow among some trees so that it can also be planted in the lowlands. An et al. (2010) explain that Amorphophallus sp is one of the tuber plants belonging to the Araceae family, Monocotyledoneae class, which grows well in

*Correspondence Author

E-mail : syihabfahmitip@gmail.com

Phone : 081334678899 tropical countries such as Japan, China, Thailand, Vietnam, Cambodia and Indonesia.

The utilization of Amorphophallus $s p$ as a food ingredient has been carried out by the Japanese and Chinese since about 15 centuries ago as traditional food in the form of noodlesand tofu. In the field of agro-industry, Amorphophallus $s p$ is processed into glucomannan. The studies on glucomannan showed that glucomannan has many applications in many fields. Glucomannan can be widely used in drug delivery such as capsule for chronic stomach disease (Wang and He, 2002). Several kinds of transparent blend films of konjac glucomannan with polyacylamide, gelatin, chitosan, xanthan sodium aginate and cellulose were invented (Xiao, Wang, and Zhang, 2002; Ye, Kennedy, Li, and Xie, 2006). In addition glucomannan can also be used to prevent obesity and tumor-related diseases. It also can be used to 
reduce cholesterol in the blood, treat diabetes mellitus, and emulsifiers (Li et al. 2006 and Chua et al. 2012).

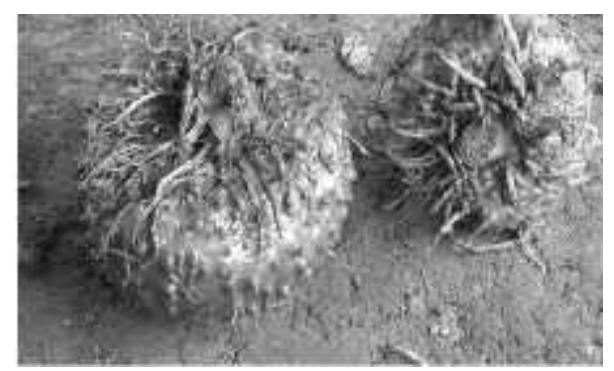

Figure 1. Amorphophallus $s p$

Recently, Indonesia - especially in East Java - has developed Amorphophallus sp cultivation. The location is Perum Perhutani Unit II in the cultivation area of $1605.3 \mathrm{Ha}$. In the aspect of cultivation, efforts have also been carried out to optimize. Those efforts include increasing the volume of production, the expansion of appropriate land, and improving the quality of production. These challenges are expected to provide significant benefits for enhancing the welfare of farmers and local people. On the other aspect (post-harvest), the effort required to produce a quality product in accordance with the standards of production, so it takes the support of appropriate technology equipment adequate and so forth. Furthermore, it is becoming necessary, to process Amorphophallus $s p$ into final products providing better added value for farmers.

The community empowerment program is a concrete plan to support, assist and facilitate the growth and development of the awareness of farmers and communities to manage the land for Amorphophallus $s p$ cultivation. The program was expected to provide benefits both in terms of economic value and in an effort to improve the welfare of society.

Dissemination, training and other forms of collaboration, that have been made should be responded well and followed up by the farmers and the community in the form of positive activities related to the cultivation. Additionally, it should also be observed the obstacles faced by both cultural and structural constraints that lead to community empowerment in the cultivation process not run properly. Therefore, the research was needed to determine and analyze the community response to the cultivation of Amorphophallus $s p$ in empowering communities. The urgency of this research was to obtain of adequate information about the condition, problems and needs associated with the substantial public response about the cultivation of Amorphophallus sp expected to be beneficial in enhancing community empowerment.

\section{Research Methods}

The object of this study was the group of farmers who have obtained the information and or implement Amorphophallus $s p$ farming activities. The data consisted of primary and secondary data. Data were collected through surveys and in-depth interviews. Observations were also made to observe and analyze the conditions of cultivation practices, post-harvest handling and the public response to Amorphophallus sp cultivation practices. The secondary data was used to describe the general state condition of research area located in four regencies namely Nganjuk, Tulungagung, and Madiun.

\subsection{Analysis}

The study will be focused on: (i) the response of the community who have obtained information on the Amorphophallus $s p$ cultivation either through socialization, training, support equipment production and post-harvest and so on, (ii) public response to the implementation of farming activities, (iii) the benefits of community development focused on several dominant aspects: community involvement in the planning, implementation and control and evaluation Amorphophallus $s p$ cultivation.

The method used in this reseach was survey method using data analysis Partial Least Square (PLS). The analysis was conducted to investigate the public response to the cultivation of Amorphophallus sp. Ghozali (2008) suggests PLS is distribution free approach (do not assume a particular distribution of data, can be nominal, category, ordinal, interval and ratio) and PLS is a powerful method of analysis because it is not based on many assumptions, small sample size and distribution residual. Although PLS can also be used to confirm the theory, but also to explain the relationship between latent variables.

The focus of this study was to analyze the public response to Amorphophallus $s p$ cultivation in empowering communities. Study design to analyze the response of the public is using the survey method with quantitative approach and inferential statistics. The study of communities 
responses could be seen from the three main aspects were as follows:

a. The public perception of Amorphophallus sp cultivation: perception is a cognitive process by any person in understanding about something through sight, hearing, feeling and acceptance. Perception is a unique interpretation of the situation. There are three things that will be analyzed related to the perception that knowledge and understanding of Amorphophallus $s p$ cultivation as well as knowledge of the purpose and benefits and the added value of Amorphophallus sp cultivation

b. Public attitudes towards Amorphophallus sp cultivation: The tendency or willingness of a person to behave in particular when faced with a condition or specific information. Aspects of public attitudes assessed include

1) The assessment of the public against the activities related to the Amorphophallus $s p$ cultivation

2) The level of public acceptance towards Amorphophallus $s p$ cultivation

3) The perceived benefits society as a direct and indirect impact of Amorphophallus $s p$ cultivation

c. Community participation on Amorphophallus $s p$ cultivation. Community partitipation is a process in which the mental attitude of society to participate actively contribute creativity and initiative in Amorphophallus $s p$ cultivate. The ccommunity participation is measured by several factors as follows:

1) The involvement and activity of the community involved in activities related to the Amorphophallus sp cultivation

2) Participating in providing responses and suggestions in the activities of formal and informal meetings related to the Amorphophallus sp cultivation

3) Participating in carrying out Amorphophallus sp cultivation activity, post-harvest handling and efforts to increase the value-added of Amorphophallus sp.

\section{Result and Discussion}

\subsection{The Area Condition of Amorphophallus sp cultivation}

Available online at HABITAT website: http://www.habitat.ub.ac.id ISSN: 0853-5167 (p); 2338-2007 (e)
Trenggalek regency have seven locations that are ready in Amorphophallus sp cultivation development. For example Dawuhan village, with a fairly high potential in agriculture, plantations and forestry, have a good chance to develop Amorphophallus sp cropps. This program was supported by the existence of the Forest Village Community Institution namely Bukit Lestari, the formation and management process is fully supported by the community.

Nganjuk regency have developed both in the forest and outside forest areas. It is consistent with the potential of land area reaching of 122 433 ha. The forest area consists of: production area of $38843.10 \mathrm{Ha}$, protected area of 10562.90 $\mathrm{Ha}$ and other purpose uses area as much as of 697.2 Ha. According to the data of Nganjuk's Forestry Department (2014). Nganjuk Regency since 2005 has conducted the activities of nontimber forest product development. The cultivation of Amorphophallus sp cropps was conducted through the realization of development of community forests in 2010 at four locations each 10 ha. The area of Amorphophallus sp plant development is still relatively small compared to the potential for community forests totaling around 8,100 hectares.

Based on the survey on LMDH it was known that the cultivation of Amorphophallus $s p$ has been accomplished in Nganjuk for seven years. These activities can be found in many districts. This potential is still being developed in line with the benefits gained, especially in increasing the economic value of land and community empowerment.

Harvesting period becomes the main concern among farmers, where they are often harvested prematurely. Harvesting period is the main concern among farmers, where they are often harvested prematurely. This case not only taken effect on the economic value, but also influence the way the next cultivation, where farmers harvest all tubers, so it was not left for the next planting.

The local government had engaged in facilitating the development of cultivation of Amorphophallus $s p$ among the following: (i) to provide guidance to the farmer groups (LMDH), (ii) providing assistance seed, and (iii) facilitating cooperation among farmers with business partners. On the other hand, Madiun Regency is one of the central areas of cultivation Amorphophallus sp. Central Bureau of Statistics (2015), there are high potential area of $1,395 \mathrm{Ha}$ 
for 8.200 ton production of Amorphophallus sp. Furthermore, Saradan districts have the highest total production of Amorphophallus sp 7471 tons per year, with total land area of 927 hectares.

Through government support, either through production to marketing assistance activities, Amorphophallus sp cultivation activity in Madiun Regency has been going well. Generally, farmers prepare the land to carry out the cleaning of weeds and made into ridges of 40$50 \mathrm{~cm}$ wide with a height of about $20-25 \mathrm{~cm}$. Land that had been planted earlier then no need special preparation. Furthermore, weeding and fertilizing done periodically for maintenance. Fertilization is done on the basis of early planting, and thereafter annually at the beginning of the rainy season.

Dorman period (April-June) is to be the best harvest time. It is characterized by most or even the whole plant looks dead, or just left to dry stems and small holes that can be used as a guide position where the Amorphophallus sp plants. If the cultivation process goes well, then the average tuber production Amorphophallus sp about 9-10 tons per hectare

Amorphophallus tubers produced by farmers were classified as good product indicated by the size and quality of tubers produced are quite good. Furthermore, some farmer has processed Amorphophallus $s p$ into a chip product, so that they can earn higher (Figure 2).

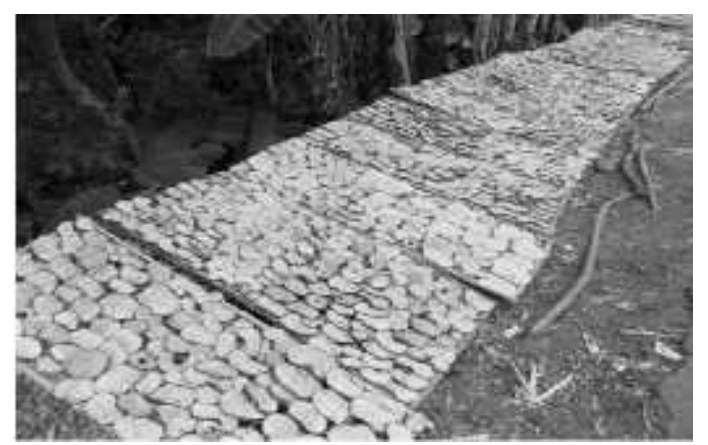

Figure 2. Drying Processing of Amorphophallus $s p$ Chip Conducted by Community

Farmers generally do manual slicing of Amorphophallus, while the use of machines is still limited by certain groups. Furthermore, the drying process takes approximately 4-5 days to make sure the chips have completely dried, thus not allowing the emergence of fungi that can affect the quality and price of product. It is what should be the concern, because farmers, knowledge, experience and commitment to be an important factor determining the quality - in the context of empowerment. The chip produced by farmers is quite good with the uniform size of around $0.5 \mathrm{~cm}$, and very few results are broken chopped disease. This will help farmers to offer Amorphophallus in a better price.

\subsection{The Model of Amorphophallus Agroindustrial Empowerment}

$s p$.

In this study, the measurement model was designed to express the relationship between indicators of the exogenous variables with reflective indicator. The outer model consists of exogenous variables $(\mathrm{X})$ and endogenous variable (Y). Furthermore, path diagram is a picture that shows the structure of a causal relationship between the independent variables and the dependent variable. A path diagram, doublepointed arrow shows the correlation and the arrows indicate the direction of causal relationship or a direct effect of the independent variables (exogenous) $\mathrm{X}$ on the dependent variable (endogenous) Y (Riduwan and Kuncoro, 2008; Latan, et al, 2017). In path diagram construction, there are two things that must be done, which is preparing the structural model (inner model) that connects between the latent exogenous variables $(\mathrm{X})$ and endogenous $(\mathrm{Y})$, and a measurement model (outer model) linking the latent variable to the indicator. The construction of path diagram in this study could be seen in Figure 3.

Based on the PLS modeling of the technology adoption variable, there was indicator that does not meet the rule of convergent validity, which has a loading factor values below 0.5 , so it is necessary to modify the model. It was done by removing or eliminating the indicator and does not putting it in the calculation. If the value of the loading factor is below 0.5 , then this indicator should be removed, because this indicator does not fit into the constructs that represent them (Jogiyanto, 2009).

Furthermore, the theoretical model has been constructed in the path diagram was converted into equations model. There are two kinds of equations in the path diagram conversion to the equation model. The structural equation was formulated to state the causal relationship between the variables studied, while the measurement equation is used to determine how much the indicators that make up the variable (Feng, 2008). In the conversion equation structural model, based on the research path diagram can be converted an equation as follows: 
$\mathrm{Y}_{1}=0,067 \mathrm{X}_{1}+0,102 \mathrm{X}_{2}+0,208 \mathrm{X}_{3}+\zeta$

$\mathrm{Y}_{2}=0,027 \mathrm{X}_{1}+0,230 \mathrm{X}_{2}+0,347 \mathrm{X}_{3}+0,013 \mathrm{Y}_{1}+\zeta$

$\mathrm{Y}_{3}=0,224 \mathrm{Y}_{1}+0,309 \mathrm{Y}_{2}+\zeta$

Y1: community attitudes

Y2: community participation

Y3: the benefits of cultivation in community empowerment

On the other hand, the conversion structural equation models is used to determine how much the indicator compose latent variable (Feng 2008). The estimation of the model offers empirical measures of the relations between the structural model and between the indicators and measuring models. The equation of specification measurement model in this study consisted of six variables:

Cultivation information $\left(\mathbf{X}_{1}\right)$ : the measurement model equation which connects the variable of cultivation information with the indicators could be seen in the following equation. Based on this equation, it was understandable that the variable cultivation information reflects the results of the indicators $\mathrm{X}_{11}, \mathrm{X}_{12}, \mathrm{X}_{15}, \mathrm{X}_{17}, \mathrm{X}_{18}, \mathrm{X}_{19}$, and $\mathrm{X}_{11}$ with the respective value of $0.668 ; 0.697 ; 0.767$; $0.739 ; 0.809 ; 0.802$ and 0.821

$$
\begin{aligned}
& \mathrm{X}_{1}=0,668 \mathrm{X}_{11}+0,697 \mathrm{X}_{12}+0,767 \mathrm{X}_{15}+ \\
& 0,739 \mathrm{X}_{17}+0,809 \mathrm{X}_{18}+0,802 \mathrm{X}_{19}+0,821 \mathrm{X}_{110}
\end{aligned}
$$

Post-harvest $\left(\mathbf{X}_{2}\right)$ : The model measurement of equation linking post-harvest variable with the indicator variables could be seen in the following equation:

$$
\begin{aligned}
& X_{2}=0,752 X_{21}+0,818 X_{23}+0,923 X_{24}+ \\
& 0,893 X_{25}+0,941 X_{26}+0,851 X_{27}
\end{aligned}
$$

The supporting of production facility $\left(\mathbf{X}_{3}\right)$. The measurement model equation that connects the variable of production facilities support with its indicators could be seen in the following equation:

$$
X_{3}=-0,533 X_{31}+0,735 X_{33}
$$

Based on the above equation, it could be seen that in the variable of the frequency acquisition of aquaculture facilities $\left(\mathrm{X}_{31}\right)$, the type and form of infrastructure support $\left(\mathrm{X}_{32}\right)$, type and form of assistance infrastructure required, reflects the results of the indicators $X_{31}$ and $X_{33}$ with the respective value - each amounting of -0.533 and 0.735 .

The competence of public attitude $\left(\mathbf{Y}_{1}\right)$. The measurement of equation model connecting people with the indicator variable attitude can be seen in the following equation:

$$
\mathrm{Y}_{1}=0,935 \mathrm{Y}_{12}+0,549 \mathrm{Y}_{14}
$$

Based on the above equation, it could be found that the public attitude variable reflects the results of the indicator $\mathrm{Y}_{12}$ and $\mathrm{Y}_{14}$ with the respective value amounted to 0.935 ; and 0.549 .

\section{Community participation $\left(\mathbf{Y}_{2}\right)$. The} measurement equation model connecting the variable of community participation with the variables, could be seen in the following equation $\mathrm{Y}_{2}=0,03 \mathrm{Y}_{21}+0,876 \mathrm{Y}_{22}+0,691 \mathrm{Y}_{23}+0,565 \mathrm{Y}_{24}$

Based on the above equation, it could be found that in the variable of community participation reflects the indicators of $Y_{21}, Y_{22}, Y_{23}$, and $Y_{24}$ with value of $0.603 ; 0.876 ; 0.691$; and 0.565 .

The benefits of cultivation in community empowerment $\left(\mathbf{Y}_{\mathbf{3}}\right)$ : equation measurement model linking the variables of cultivation the benefits of community empowerment with the indicator can be seen in the following equation: $\mathrm{Y}_{3}=0,836 \mathrm{Y}_{31}+0,842 \mathrm{Y}_{32}+0,624 \mathrm{Y}_{33}+0,624 \mathrm{Y}_{34}$ Based on the above equation, it could be found that the variable of the benefits of farming in community development reflected the results of the indicator of $\mathrm{Y}_{31}, \mathrm{Y}_{32}$, and $\mathrm{Y}_{34} \mathrm{Y}_{33}$ the respective value amounted of 0,$836 ; 0.842$; 0,624 ; and 0,624 .

Furthermore, hypothesis test was used to analyze the effect of partially exogenous variables $(\mathrm{X})$ against endogenous variable $(\mathrm{Y})$. Hypothesis testing in this study was conducted to see the value of t-values on each path. $t$-value was obtained by bootstrapping with Smart-PLS software, which aims to minimize the problem of abnormalities of research data (Ghozali, 2008). The coefficient of inner weight of the structural model is said to be significant on the condition value $t$ count $>\mathrm{t}$-table of 1.96 . The result of direct test was presented on the Table 1.

Table 1. Direct Impact Testing Result

\begin{tabular}{lllll}
\hline No. & $\begin{array}{l}\text { Influence } \\
\text { Between } \\
\text { Variables }\end{array}$ & $\begin{array}{l}\text { Path } \\
\text { Coeficient }\end{array}$ & $\begin{array}{l}\text { T- } \\
\text { Statistics }\end{array}$ & Information \\
\hline 1. & $\mathrm{x} 1 \rightarrow \mathrm{y} 1$ & 0.066839 & 0.501006 & Not significant \\
\hline 2. & $\mathrm{x} 1 \rightarrow \mathrm{y} 2$ & 0.027805 & 0.12667 & Not significant \\
\hline 3. & $\mathrm{x} 1 \rightarrow \mathrm{y} 3$ & 0.023585 & 0.267007 & \\
\hline 4. & $\mathrm{x} 2 \rightarrow \mathrm{y} 1$ & 0.102389 & 1.153215 & Not significant \\
\hline 5. & $\mathrm{x} 2 \rightarrow \mathrm{y} 2$ & 0.231078 & 1.594231 & Not significant \\
\hline 6. & $\mathrm{x} 2 \rightarrow \mathrm{y} 3$ & 0.094442 & 1.582607 & \\
\hline 7. & $\mathrm{x} 3 \rightarrow \mathrm{y} 1$ & 0.204595 & 0.849652 & Not significant \\
\hline 8. & $\mathrm{x} 3 \rightarrow \mathrm{y} 2$ & 0.349363 & 0.994863 & Not significant \\
\hline 9. & $\mathrm{x} 3 \rightarrow \mathrm{y} 3$ & 0.153948 & 0.898129 & \\
\hline 10. & $\mathrm{y} 1 \rightarrow \mathrm{y} 2$ & 0.012838 & 0.111674 & Not significant \\
\hline 11. & $\mathrm{y} 1 \rightarrow \mathrm{y} 3$ & 0.228141 & 2.475176 & Significant \\
\hline 12. & $\mathrm{y} 2 \rightarrow \mathrm{y} 3$ & 0.309375 & 2.011225 & Significant \\
\hline
\end{tabular}


Based on the direct effect in Figure 2 and Table 1 obtained significant results between these variables as bellow:

1) Cultivation information $\left(X_{1}\right)$, the support of production facilities $\left(\mathrm{X}_{3}\right)$ and Postharvest information $\left(\mathrm{X}_{2}\right)$, did not significantly influence people's attitudes $\left(\mathrm{Y}_{1}\right)$. It was because the value of the $t_{\text {statistic }}$ $<t_{\text {table }}$ (1.96), so the hypothesis is rejected. The results of this test gives the sense that any change both increases and decreases variable, cultivation information $\left(\mathrm{X}_{1}\right)$, information of post-harvest $\left(\mathrm{X}_{2}\right)$, and the support of production facilities $\left(\mathrm{X}_{3}\right)$, was not a significant impact on community attitudes $\left(\mathrm{Y}_{1}\right)$.

2) Cultivation information $\left(X_{1}\right)$, the information of post-harvest $\left(\mathrm{X}_{2}\right)$, the support of production facilities $\left(\mathrm{X}_{3}\right)$, and community attitudes $\left(\mathrm{Y}_{1}\right)$ had no significant effect on community participation $\left(\mathrm{Y}_{2}\right)$. It was because the values of $t_{\text {statistic }}<t_{\text {table }}(1.96)$, so the hypothesis was rejected. The test results give the sense that any change of variables, information culture $\left(\mathrm{X}_{1}\right)$, the information of post-harvest $\left(\mathrm{X}_{2}\right)$, the support of production facilities $\left(\mathrm{X}_{3}\right)$, and community attitudes $\left(\mathrm{Y}_{1}\right)$, was not a significant impact on community participation $\left(\mathrm{Y}_{2}\right)$.

3) Variable attitude of society $\left(Y_{1}\right)$ and public participation $\left(\mathrm{Y}_{2}\right)$ significantly affects the benefits of aquaculture to the empowerment of communities $\left(\mathrm{Y}_{3}\right)$. This is because the values of $\mathrm{t}_{\text {statistic }}<\mathrm{t}$ table (1.96), so the hypothesis was accepted.

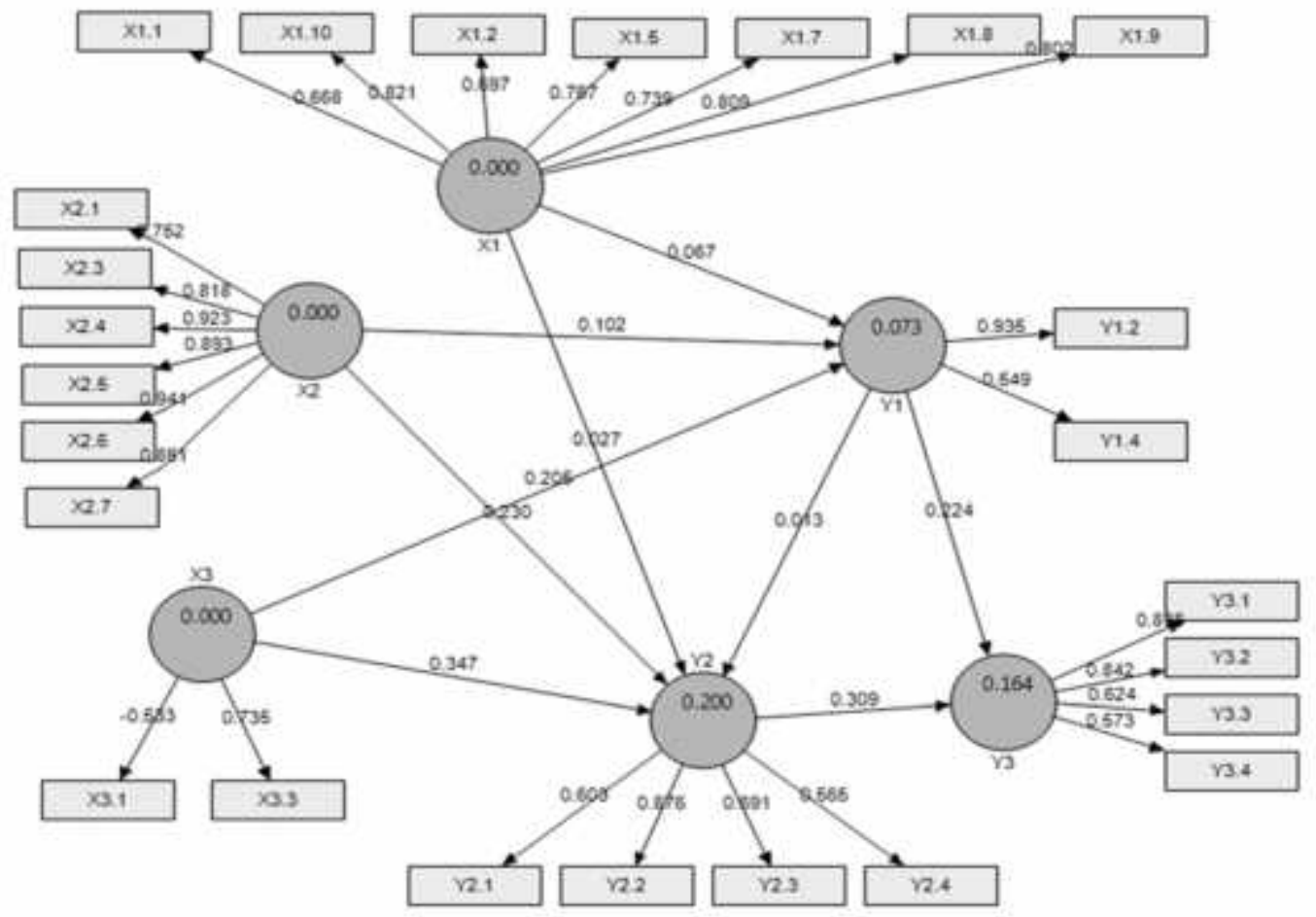

Figure 3. Path Diagram Constructing

These test results provide an understanding that any change of public attitudes variable $\left(\mathrm{Y}_{1}\right)$ and the community's participation $\left(\mathrm{Y}_{2}\right)$ significant impact on the community empowerment process $\left(\mathrm{Y}_{3}\right)$.

These results were consistent with the results of the study conducted by Achmadi and Agie (2013) which explains the significant positive effect on the attitude and public participation in the policy creation of a tourist village. The community participation is a crucial factor in achieving success and sustainability of development programs (Yulianti, 2012).

The participation means the participation of a person or group of people in the activity consciously. The public participation is very important in the overall development process. The success of development program is determined by the level of community participation.

In the process of community empowerment, participation is needed overall 
development process. This concept provides an understanding of community participation in development, if the people directly involved in the overall development process. It aims to provide a space for the public benefit and foster a sense of community ownership of a development program, so that sustainability can be achieved.

\section{Conclusion}

The community already have the knowledge of Amorphillus sp cultivation. The communities have experienced to implement postharvest practices such as chip-making Amorphophallus sp . On the other hand, the community response on the implementation Amorphillus sp cultivation has been good, and feel the benefits of cultivating mainly from the economic aspect. Due to economic factors, some people still sell the bulbs Amorphillus sp without process into a more value-added products. PLS analysis showed that the variable of community attitude and participation significantly affected the benefits of cultivation in the community empowerment. The higher the participation of Amorphilus $s p$ farming community, the better the achievement of community empowerment. However, the variable of cultivation information, the variable of the information of post-harvest handling, and the variable of supporting facilities did not significantly influence the community response. Furthermore, the variable of cultivation information, the variable of information of postharvest handling, the variable of supporting facilities, and the variable of society attitude did not significantly influence on the community participation.

\section{References}

An TN, Thien DT, Dong NT, Dung PL,Du NV. 2010. Characterization of Glucomannan from some Amorphophallus species in Vietnam. Carbohydr Polym. 80: 308-311.

Achmadi and Agie. 2013. Analysis of Attitudes and Community Participation in the Formation of Tourism Villages. Hospitality Department, Trisakti College of Tourism.

Central Bureau of Statistics. 2015. Madiun In Figures. Forestry and Plantation Office of Madiun Regency, East Java.

Chua M, Chan K, Hocking TJ, Williams PA, Perry CJ, Baldwin TC. 2012.
Methodologies for the extraction and analysis of konjac glucomannan from corms of Amorphophallus konjac K. Koch. Carbohydr Polym. 87:2202-2 210.

Feng, Y. 2008. Partial Least Squares Regression Based Cellular Automatic Model for Simulating Complex Urban System. The International Archives of Thee Photogrammetry, Remote Sensing and Spatial Information Science. 3 (2): 225276.

Ghozali, I. 2008. Structural equation modelling metode alternatif dengan partial least square (Alternative method of structural equation modeling with partial least square). UNDIP. Semarang.

Jogiyanto, HM. (2009). Analysis and design. Yogyakarta: Andi OFFSET.

Latan, Hengky, Noonan, and Richard. 2017. Partial Least Square: Basic Concepts, Methodological Issues and Applications. Springer.

Li B, Xie B, Keneedy JF. 2006. Studies on the molecular chain morphology of konjac glucomannan. Carbohydr Polym. 64: 510515 .

Wang, K. and He,Z.(2002).Alginate-konjac glucomannan-chitosan beads as controlled release matrix. International Journal of Pharmaceutics, 244(1-2), 117-126.

Xiao,C ,Weng,L and Zhang,L. (2002). Improvement of physical properties of cross linked alginate and carboxymethyl konjac glucomannan blend films. Journal of Applied Polymer Science (84) 25542560.

Ye,X.,Kennedy,J.F.,Li,B.,\&Xie,B.J.(2006).Cond ensed state structure and biocompatibility of the konjac glucomannan/chitosan blend films. Carbohydrate Polymers. 532-538.

Yulianti Y. 2012. Analysis of community participation in the implementation of the national community empowerment program (PNPM) -Mandiri Urban in Solok City. Research journal. 